\title{
Legal aid for person with disabilities in access to justice
}

\author{
Rosmalinda* and Arif \\ Faculty of Law, Universitas Sumatera Utara, Medan, Indonesia
}

\begin{abstract}
Some criminal cases took place in palm oil plantation and agriculture area as the crime scene. Unfortunately, the cases involved children and women. This paper discusses on the research results of a study on the development of legal aid model for marginal people including people with disabilities. There were two research questions namely the situation of PwD and how they access the justice. The data were collected through literature review and field study. There were 52 persons who participated in in-depth interview and 3 Focus Group Discussion. All informants are $\mathrm{PwD}$ and people who supported PwD. This study figured out a case of sexual harassment which located in palm oil plantation. The victim is a girl with hearing impairment. The result of the study shows that PwD could not access the justice due to the distance and lack of information concerning legal aid provider. Furthermore, data of PwD is not available properly either at the government office or Community Social Organization (CSO)
\end{abstract}

\section{Introduction}

Every citizen is equal before the law. This sentence should be applied equally without exceptions. In fact, there are some cases which marginalize people who facing problem to access justice. They could not access the justice properly due to their condition, for example people who live in plantation and agriculture area. [1] Distance became their problem since the area is lack of public transportation. Other is persons with disabilities. They found that it is difficult to access the justice due to their conditions. [2] This situation must be eliminated especially since Indonesia has ratified the Convention on the Rights of Persons with Disabilities (CRPD) through Law No. 19/2011 and Law Number 8/2016 concerning Persons with Disabilities. Some Researchers and Authors who are concerned with the issue of the fulfilment of the rights of persons with disabilities have also undertaken similar research with this research and published them. Two of the researchers and writers referred to here are Muhammad Joni Yulianto in his article on the Indonesian Legal Aid Handbook in chapter 9 entitled "Rights of Persons with Disabilities"[3] and Rahayu Repindowaty Harahap and Bustanuddin in their article entitled "Legal Protection of Persons with Disabilities Convention On the Rights of Persons With Disabilities (CRPD)" in an Innovative Journal published in 2015. [4]

\footnotetext{
* Corresponding author: rosmalindarohan@gmail.com
} 
The Journal shows the situations of injustice experienced by persons with disabilities that occurred before 2016. It was when Indonesia has ratified the Convention on the Rights of Persons with Disabilities (CRPD) through Law No. 19/2011. Indonesia just has a new National Law concerning Persons with Disabilities in Law No 8 of 2016. The absence of this National Law turned out to be the reason for Law Enforcement Officials and the government at all levels cannot implement or run programs that can provide justice for Person with Disabilities (PwDs). The situation is almost the same in Children who conflict with the Law (Anak yang berhadapan dengan Hukum/ABH) as the authors findings when doing research in 2014. That year, the author conducted research on the Application of the last resort principle on Children Criminal Actors in Medan City and Deli Serdang. This study looks at the situation of Children facing the Law (ABH) accessing justice. This is important considering that on August 1 in 2014, Law No. 11 Year 2012 on the Criminal Justice System of Children which well knows as Sistem Peradilan Pidana Anak (SPPA) applies. The results show that in 2014 there is no Law Enforcement Officers which well know in Indonesia as Aparat Penegak Hukum (APH) capable of providing justice to ABH as mandated in Law No. 11 of 2012. The reason of APH is the absence of obligation of APH to implement the last resort principle through diversion and restorative justice because the law is not yet valid or new without its implementing regulations.

Based on ABH research findings above, in the year 2016 the author conducted a study entitled "Model Legal Assistance for Disabled (People with Special Needs) Facing the Law in Medan \& Binjai City." This study aims to see model of legal assistance which provided for marginal people especially PwD and to ensure that PwD access the justice.

\section{Research question(s)}

The study tried to obtain answers on the research question namely the situation of person with disabilities in Medan and Binjai. Furthermore, the questions figure out the way of the person with disabilities in accessing their right before the law.

These two questions were developed further in order to get clear information for the study for example how many persons with disabilities are in Medan and Binjai?, how many of them faced legal cases?, do they access the legal aid to access justice?, how they get justice through the court decision?.

\section{Research Methodologies}

The study was conducted using literature studies and field studies. [5] In the literature study, it aims to inventory the current positive law regulation in Indonesia about PwD, legal aid and the model of legal aid provided for the victim. Meanwhile, in field research, it conducted to see the situation of people with disabilities in accessing the legal aid. [6]

This study was conducted in the city of Medan and Binjai based on both cities have Legal Aid Organization or also known in Indonesia as Organisasi Bantuan Hukum (OBH) that become partners' of ministry of Justice and Human Rights (KemekumHAM) Sumatra province. Furthermore, these research locations have legal cases with agriculture and plantation area as the criminal scene.

In the literature study, researchers used the Law no. 19 of 2011 concerning the ratification of the Convention on the Rights of Persons with Disabilities (CRPD) and the National Law no. 8 of 2016 on Persons with Disabilities. As for legal assistance, Researchers use Law No. 16 of 2011 on Legal Aid. In addition, the researcher also uses court decisions on cases of persons with disabilities in the city of Binjai namely the Decision of PN Binjai Number: 85 / Pid.B / 2013 / PN.BJ. which is reinforced by the 
Medan High Court Verdict Number: 427 / PID / 2013 / PT-MDN. Both of these decisions are important to be included based on the situation of victims with disabilities who lived in plantation area and her parents are farmer.

Researchers conducted in-depth interviews and FGDs to informants which can be classified into 3 groups namely:

1. Group of PwDs; they are PwDs with legal or non-disability.

2. Supporting Groups of Disabling Supporters; They are parents, families and teachers of persons with disabilities

3. Legal Service Provider and Support Group; Law Enforcement Officials such as Police, Prosecutors and Judges, Advocates from Legal Aid Organizations who are partners and not partners of KemenkumHAM Sumatera Utara Province

In detailed, the field study was conducted through in-depth interviews and involved 17 informants that can be categorized as below.

Table 1 Information of Informants.

\begin{tabular}{|c|l|c|c|c|c|c|}
\hline No & \multicolumn{1}{|c|}{ Group } & \multicolumn{2}{|c|}{$\begin{array}{c}\text { Number of In-depth } \\
\text { Interview Informants }\end{array}$} & \multicolumn{2}{c|}{$\begin{array}{c}\text { Number of FGD } \\
\text { Informants }\end{array}$} & \multirow{2}{*}{ Total } \\
\cline { 3 - 6 } & & Male & Female & Male & Female & \\
\hline 1 & $\begin{array}{l}\text { Person with Disabilities } \\
\text { (PwD) }\end{array}$ & 5 & 3 & 13 & 9 & 8 \\
\hline 2 & People who supported PwD & 2 & 3 & 3 & 4 & 5 \\
\hline 3 & Legal Aid provider & 2 & 2 & 3 & 3 & 4 \\
\hline & & 9 & 8 & 19 & 16 & 52 \\
\hline
\end{tabular}

\section{Results and discuss}

The document study noted that the notion of persons with disabilities is almost the same between Law no. 8 of 2016 on Persons with Disabilities and Law no. 19 of 2011 on the ratification of the Convention on the Rights of Persons with Disabilities (CRPD) see Table 1. Having similarities, persons with disabilities include physical, mental, intellectual or sensory for long periods of experiencing similar problems and must obtain equality as citizens.

Table 2 Definition of Person with Disabilities.

\begin{tabular}{|c|c|}
\hline $\begin{array}{c}\text { Law No. 19/2011 concerning the Ratification } \\
\text { of Convention on The Rights of Person with } \\
\text { Disabilities (CRPD).[7] }\end{array}$ & $\begin{array}{c}\text { UU No. 8/2016 concerning Person with } \\
\text { Disabilities. [8] }\end{array}$ \\
\hline $\begin{array}{c}\text { Persons with disabilities include those who have } \\
\text { long-term physical, mental, intellectual or } \\
\text { sensory suffering where interactions with } \\
\text { multiple barriers may make it difficult for full } \\
\text { and effective participation in society on an equal } \\
\text { basis with others (Article 1) }\end{array}$ & $\begin{array}{c}\text { Persons with disabilities are anyone who } \\
\text { experiences long-term physical, intellectual, } \\
\text { with the environment may experience barriers } \\
\text { and difficulties to participate fully and } \\
\text { effectively with other citizens on the basis of } \\
\text { equal rights (Article 1 Number 1) }\end{array}$ \\
\hline
\end{tabular}

Based on this definition, study found out the answer of research question is Medan and Binjai. Medan is the capital of Sumatera Utara province consisting of 21 (twenty one) sub districts and 151 urban-communities. Based on data from the Central Bureau of Statistics (BPS) in North Sumatera in Figures 2015, stated that the population of Medan amounted to 2,191,140 people $(1,081,797$ male and 1,109,343 female) while Binjai as the closest city to 
Medan which bordered with Deli Serdang Regency. Binjai City consists of 5 sub-districts which then divided into 37 villages and villages with a population of 261.40 people (130,551 male and 130,938female).[9] Some urban communities in Medan and Binjai are bordered with palm oil plantation area. After carrying out research for 1 year in Medan and Binjai. The study obtained results which will be discuss as below.

\subsection{Data of PwD and legal cases}

There were not clear data on the number of persons with disabilities in Medan and Binjai in the duration year of 2015 to 2016 see Table 1. Until the end of the study, there was only data on the number of persons with disabilities based on institutions where people with disabilities engage in activities. For example in Medan; Yayasan Pendidikan Tunanetra (Yapentra) and Social Institution titled Bina Daksa Bahagia Sumut. This institution is a program which provided by ministry of social affair in Jakarta. Meanwhile, in Binjai, data is only provided by public extraordinary school (Sekolah Luar Biasa/SLB). There was not fitted official data of Pwd in Medan dan Binjai which provided by government institution such as district social departments.

There was only data of PwD in 2006 while for 2016, there is not any data. The staff of district social department in Binjai just mentioned that there are 850 persons with disabilities in Binjai. However, there is not any further explanation about the data. Similarly, in the Social Service and Manpower Office of Medan, after several bureaucratic problems, the study only obtained information about the number of persons with disabilities who received program assistance without further explanation, see Table 3.

Table 3 Number of students in SLB Negeri Binjai in 2016

\begin{tabular}{|c|c|c|c|c|}
\hline \multirow{2}{*}{ No } & \multirow{2}{*}{$\begin{array}{c}\text { Type of } \\
\text { Disabilities }\end{array}$} & Male & \multirow{2}{*}{ Female } & \multirow{2}{*}{ Total } \\
\cline { 3 - 4 } & \multicolumn{5}{|c|}{ Primary School } \\
\hline 1 & Vision & 2 & 9 & 11 \\
\hline 2 & $\begin{array}{c}\text { Hearing } \\
\text { impairment }\end{array}$ & 18 & 11 & 29 \\
\hline 3 & $\begin{array}{c}\text { Mentally } \\
\text { Disable }\end{array}$ & 42 & 29 & 71 \\
\hline 4 & $\begin{array}{c}\text { Physical } \\
\text { disability }\end{array}$ & 8 & 0 & 8 \\
\hline 5 & Autism & 8 & 0 & 8 \\
\hline \multicolumn{7}{|c|}{} & $\begin{array}{c}\text { Hearing } \\
\text { impairment }\end{array}$ & 10 & 18 & 28 \\
\hline 1 & $\begin{array}{c}\text { Mentally } \\
\text { Disable }\end{array}$ & 7 & 3 & 10 \\
\hline 3 & Vision & 0 & 1 & 1 \\
\hline 4 & $\begin{array}{c}\text { Physical } \\
\text { disability }\end{array}$ & 1 & 0 & 1 \\
\hline
\end{tabular}




\begin{tabular}{|c|c|c|c|c|}
\hline 1 & $\begin{array}{c}\text { Hearing } \\
\text { impairment }\end{array}$ & 4 & 5 & 9 \\
\hline & Total & 106 & 81 & 187 \\
\hline
\end{tabular}

Based on the results of the research mentioned above, it strengthens the results of research and mentoring on people with disabilities that already exist namely the absence of an official data of PwD in Medan. This opinion was submitted by Director of United Evangelical Mission (UEM) in December 2015 in one daily in Medan City. [10] In this study, although the team tried to through the process of bureaucracy to obtain data from the Social Service and the Manpower of Medan City and Binjai City Social Service but there was not any suitable data. The absence of this data according to the Social Service staff of the two cities is based on the large number of SKPD work program target groups. Another cause of the absence of data of PwD is the absence of disaggregated data from institutions that are concerned with PwD either by sex, age or residence.

According to data from informants offices such as Police, legal aid offices, in the period of 4 latest years namely from 2013 to 2016, there were 5 legal cases which involved persons with disabilities in Medan and Binjai. The cases are sexual harassment. All of the cases positioned children as victims.

Table 4 Legal Case Involving Person with disabilities.

\begin{tabular}{|c|c|c|c|c|c|}
\hline No & Year & $\begin{array}{c}\text { Type of } \\
\text { Cases }\end{array}$ & Status & Police Area & $\begin{array}{c}\text { Legal Aid } \\
\text { Organization }\end{array}$ \\
\hline \multicolumn{6}{|c|}{ Kota Medan } \\
\hline 1 & 2015 & $\begin{array}{c}\text { Sexual } \\
\text { harassment }\end{array}$ & $\begin{array}{l}\text { Witnesses } \\
\text { (Parents } \\
\text { Victim) }\end{array}$ & $\begin{array}{l}\text { Polsek } \\
\text { Sunggal }\end{array}$ & PKPA \\
\hline 2 & 2015 & Incest & Perpetrator & $\begin{array}{l}\text { Polresta } \\
\text { Medan }\end{array}$ & PKPA \\
\hline \multicolumn{6}{|c|}{ Kota Binjai } \\
\hline 1 & 2016 & Rape & Victim & Polres Binjai & PKPA \\
\hline 2 & 2014 & $\begin{array}{c}\text { Sexual } \\
\text { Harassment }\end{array}$ & Perpetrator & $\begin{array}{l}\text { Stop at the } \\
\text { police desk }\end{array}$ & - \\
\hline 3 & 2013 & Rape & Victim & $\begin{array}{l}\text { PT Medan; } \\
\text { Province } \\
\text { Court }\end{array}$ & $\begin{array}{l}\text { Lukman \& } \\
\text { Association }\end{array}$ \\
\hline
\end{tabular}

Based on data which stated above, one of the legal case is PN Binjai Number: 85 / Pid.B / 2013 / PN.BJ. This legal case reinforced by appeal court in Medan High Court (PT Medan) Number: 427 / PID / 2013 / PT-MDN. It declared the defendant proven legally and convincingly guilty of committing a crime which located in a palm oil plantation area in Binjai. This fact is supported World Rainforest Movement finding on the situation of palm oil plantation in Indonesia and Malaysia. It states that the number of sexual harassment including rape is increased since the area changed to be a palm oil plantation.[11]

\subsection{PwD and accessing the legal aid}

Based on in-depth interviews and Focused Discussions it is known that knowledge and experience of accessing legal aid are different among PwD and the supporting people of PwD. This difference was mentioned by informants in FGD which involved SLB teachers, 
police and parents of PwD. There are 2 main reasons why people with disabilities did not access legal aid although there is a legal aid provider which registered based on Law Number 16/2011 concerning legal aid,[12] namely:

1. Victims and witnesses of PwD or families of victims and perpetrators of PwD are afraid to advocate their right due to the cost is very expensive. They explained further, since they lived in the palm oil plantation area which is far from the city centre, they need to pay more for their transportation.

2. Victims who is PwDs could not communicate properly with APH or legal counsel for two reasons;

2.1. Both APH and legal aid provider staffs could not speak sign language which use by people with hearing impairment. They need an interpreter. Unfortunately. The victim was never sent to school because as farmers they do not have enough money to send their daughter to the SLB in Binjai. Lack of public transportation from their house which is in the palm oil plantation becomes the main consideration to not send the girl to SLB. As consequences, the girl is lack of education. Furthermore, when the girl accessed legal aid, no interpreter could understand her sign language. She used informal sign language while the interpreter used the formal one.

2.2. Actually, family such as her uncle understand her informal sign language. However it was 'taboo' in the community for elder people talked directly to the girl about the incident of sexual harassment.

Lacks of education is a factor of poverty. In specific, being illiterate inhibiting women to access their rights.[13] It can be seen in the legal case process of PN Binjai case Number: 85 / Pid.B / 2013 / PN.BJ. and the appealed case Number: 427 / PID / 2013 / PT-MDN. The victim could not access legal aid service by herself. She needed someone in her family, unfortunately due to her condition as PwD and never sent to school, she faced big problem while through the process of justice especially in communication.

Other study result shows 3 factors of people who supported PwD which contributed to the difficulties of PwD in accessing the justice.

1. The distance; both police and legal aid provider mentioned that they do not have special fund to go to the remote area such as Plantation and agriculture area to provide legal services. Police add some information concerning fund, although they have fund to go to remote area in order to provide security for society, they could not do it usually. They had to share the fund to other cases in different area.

2. Limited capacity of human resources; there was not any police who understand the sign language. When they handled the case of the girl with hearing impairment, they need to hire an interpreter from SLB Binjai. Similar problem also appeared among the staff of legal aid provider. No one in the legal aid office understands the sign language.

This study supported the opinion of Muhammad Joni Yulianto which mentions "... In general, the rights of PwDs are violated by investigators and judges including equality before the law and the right to a fair trial. [2] In the PN Binjai case Number: 85 / Pid.B / 2013 / PN.BJ. and the appealed case Number: 427 / PID / 2013 / PT-MDN shows that the rights of PwD are violated by the law enforcers due to their lack of capacity and facility in sign language. As a citizen, the victim should have proper interpreter while the law process starting from the police office to the court.

Another writer, Rahayu Repindowaty Harahap and Bustanuddin in his article entitled "Legal Protection of Persons with Disabilities by the Convention on the Rights of Persons with Disabilities (CRPD)" mentions the same thing as Muhammad Joni Yulianto regarding Legal Services for PwDs in Indonesia who are still poor. Two basic reasons are: First, there are no rules of gender and disability. Secondly, the availability of the budget especially to 
provide referrals or referrals of expert witness which related systems including translators particularly for women and girls with disabilities of sexual violence. [2]

This second reason is reinforced by the findings of researchers in another case accompanied by the Legal Aid Organization (OBH) in Medan. Based on the results of interviews Researchers with $\mathrm{OBH}$ staff found that currently, $\mathrm{OBH}$ is assisting Disabled Persons (Witness), parents of victims of sexual abuse by the victim's parents. Perpetrators of PwD, visually impaired persons working in the Disabled Massage Home of the Disabled Persons, parents of 3-year-old child victims. This incident was reported by the victim's parents after previously reported the incident to the Polsek or sub-district police office. But the case stalled because the victim's parents found barriers to mobilization to $\mathrm{OBH}$ and Polsek. On the other hand both OBH and Polsek do not have specific human resources and budget to provide intensive assistance to PwDs (witnesses), parents of victims of sexual violence.

\subsection{Justice in the court decision}

It stated above that PwDs are violated by people who work as law enforcers. It appear not only due to lack of communication while the legal process but also appears in the court decision. According to the case as stated above which involved a hearing impairment girl as victim of sexual harassment located in palm oil plantation? This study shown that the rape case is worse due to the victims of PwDs was still 16 years old and never attended the SLB. Victims were raped by two perpetrators. The perpetrators, 3 other witnesses and the victim were burning corn near the palm oil plantation in Binjai. In specific, the criminal scene was near to the soccer field of the palm oil plantation area. Although, the perpetrator has been found guilty in accordance with the Decision of PN Binjai Number: 85 / Pid.B / 2013 / PN.BJ. Final court, PT Medan, decided a decision Number 427 / PID / 2013 / PT-MDN which imposed the criminal sanction against the defendant with imprisonment for 8 (eight) years and a fine of IDR. 100.000.000, - (one hundred million rupiah). The court provided other substitute punishment that is if the fine is not paid by the defendant then it can be replaced with 2 (two) months prisons.

The study found that the punishment which was given to the offender is not comparable with the impact that must be burdened by the victim. As stated in this writing, today, the victim is caring her child who was born from the defendant's actions. She does not have any help from the defendant. The victim is a single parent when she was 19 years old. Moreover, based on the court decision, the perpetrator got punishment for the crime committed, while the victim also get restitution rights for the acts that he experienced. In fact, it was not happened. As a basis for implementing the right of restitution for the victims there is mentioned in Law no. 31 Year 2014 about Amendment to Law no. 13 of 2006 on the Protection of Witnesses and Victims. For this purpose the government should help the victims to get their restitution right. [14] In fact, the victim does not get the restitution as stated in the court decision.

This case is really different compare to a case of sexual assault of sexual abuse and rape which conducted 6 times and involved a PwD victim in Sukoharjo. The victim is a student who attended Public High School (SMU) SLB and was 22 years old. The perpetrator is a teacher who teaches in the field of art and computer studies. This crime occurred in 2012 and after going through a judicial process that is almost 1 year, finally the trial in Sukoharjo District Court was won by the victim with the enactment of decision number 28 / Pid.B / PN.SKH with the verdict 8 years 6 months. Subsequently the defendant filed an appeal and obtained Decision No 244 / Pid 2013 / P.T.Smg which strengthens PN Sukoharjo.[2] 


\section{Conclusions}

There are three conclusion and suggestion. First, although, there is not any official data concerning PwD in the district level, government should communicate with persons and institution that have concern on PwD for example conducting a regular meeting at the government office. Furthermore, legal aids are needed for marginal society including people with disabilities in palm oil plantation. Both legal aid and legal enforcers such as police, prosecutors and judges need to gain skill in sign language especially for the law enforcers who are pointed as special officer for cases of children and women. Last but not least, justice should belong for everyone including PwDs. When she accessed for justice, it is a must for law enforcers, judges in particular to accommodate her wills. As impact, she will be able to be independent on her war to achieve prosperity.

\section{Acknowledments}

We would like to thank the Research and Service Institute of Universitas Sumatera Utara who supported the research program through HIBAH BERSAING Scheme of fiscal year 2016 with based on the Rector letter No. 154 / UN5.2.3.1 / PPM / SP / 2016.

\section{References}

1. Agus Purwoko, Ketut Sukiyono, and Basuki Sigit Priyono, The Incidence Probability of Violence Against Women: Case Study At Agricultural Society In District of North Bengkulu, JS, 13, 58-75 (2011)

2. Rosmalinda, Arif, Ainul Mardiah, Pendampingan Hukum Bagi Penyandang Disabilitas di Kota Medan dan Binjai (Studi Kasus Pelaku Kekerasan Seksual), SINDN USU, 209 (2016)

3. Muhammad Joni Yulianto, Hak-Hak Penyandang Disabilitas, in Panduan Bantuan Hukum Di Indonesia, 252-282 (2014)

4. Rahayu Repindowaty Harahap and Bustanuddin, Perlindungan Hukum Terhadap Penyandang Disabilitas Menurut Convention On The Rights Of Persons With Disabilities (CRPD, JI, VIII, 28 (2015)

5. Solly Lubis, Filsafat Ilmu dan Penelitian, (2013)

6. Sulistiyowati Irianto, Praktik Penelitian Hukum: Persfektif Sosiolegal dalam Metode Penelitian Hukum; Konstelasi dan Refleksi, 297-315 (2011)

7. Undang-Undang No. 19 tahun 2011 tentang Ratifikasi Convention on The Rights of Person with Disabilities(CRPD)

8. Undang-Undang No. 8 tahun 2016 tentang Penyandang Disabilitas

9. Badan Pusat Statistik, Sumatera Utara dalam Angka 2015 (2015)

10. http://www.tribunnews.com/regional/2015/12/03/tak-ada-jumlah-pasti-penyandangdisabilitas-di-medan,

11. Jutta Kill Y Winfridus Overbeek, 13 replies to 13 lies about oil palm monoculture plantation, 13 (2018)

12. Undang-Undang No 16 tahun 2011 tentang Bantuan Hukum

13. Lies Marcoes, Achieving Gender Justice In Indonesia's Forest and Land Governance Sector, How civil society organisations can respond to mining and plantation industry impacts, 4 (2015) 
14. http://www.hukumonline.com/berita/baca/lt57504006f0138/ingat-korban-kekerasanseksual-juga-punya-hak-restitusi, 